\title{
Social inequalities and health crises: the forgotten and leave them behind
}

\begin{abstract}
The 2003 WHO report begins with the words of its Director-General who said: "Today, the global health situation forces us to ask ourselves urgent questions about equality in health. In some areas one can expect to live longer and more comfortably while in others one despairs of being able to contain disease when the means to do so are known". To illustrate this inequality, the report states that a girl born in Japan has a life expectancy of 85years; if she was born in Sierra Leone, her life expectancy will not exceed 36years. G. Pison ${ }^{1}$ confirms that the risk of death for a child under the age of five years is less than 10 by 1000 in North America and in sub-Saharan Africa from 100 and over 150 by 1000. This striking and real inequality is not only due to the variation of the availability of public health here and there; many other factors exacerbate it, such as poverty, wars, institutional instability or systems of governance. However, in 1986, the first International Conference for the Promotion of Health in Ottawa (Canada) issued a charter for action aimed at health for all by 2000 ; this charter notes that the preconditions are peace, shelter, food and income. We are still far from it in many regions of the world in 2020. An analysis of national private health expenditure from the data repository of the WHO Health Observatory shows us that the ration between the regions of developing countries and those of technologically advanced countries varies between 17\% (year 2003) and 20.6\% (year 2017); we are still very far from the millennium goals. Covid-19 pandemic has accentuated these inequalities and one wonder how will be the reaction of the advanced countries when faced with situations as in poor countries; we remember all the attempts of some to seize the means to fight and prevent the pandemic as soon as it appears. Covid-19 pandemic has clearly accentuated these inequalities. At a time when laboratories in northern countries are racing for vaccines, and technologically advanced countries are racing to reserve and share the quantities needed for their consumption, unfortunately no-one is considering the fate of poorer populations. Yet she is not the first that the world has known. There have
\end{abstract}

Volume I4 Issue I - 202I

\author{
Abdellaoui Abdelkader \\ Department of Formation, Avicenna Virtual Campus Network, \\ France
}

Correspondence: Abdellaoui Abdelkader, Avicenna Virtual Campus Network, Paris, France, Tel 33 652489|49,

Email Abdellaoui.geo@gmail.com

Received: December 02, 2020 | Published: February 19, 2021

been others as deadly, if not more ; we can cite the bubonic plague which had reappeared in 1320 in Mongolia ; it had remained endemic in the East, India and China ; it then appeared in the West in 1347 brought back by Genoese sailors fleeing Caffa and caused the death of 25 to 40million Europeans.

Following this, it is time to ask many questions about the responsibility of technologically advanced countries. They need to contribute in a humane and effective way to the distress of poor countries. They should also consider countries plagued by multiple factors of instability to really take charge; while remembering all the same that these factors are not all of their responsibility to quote only the drawing of the borders resulting from the decolonization or even before the division of the territories between conquerors.

This article attempts to ask these questions, but does not attempt to answer all questions especially the complex ones. We will present, by way of illustration, the case of a locality in a Maghreb country, which had been the subject of numerous works by the author or his students.

Keywords: socio-health inequalities, corona virus, social pressure

\section{Introduction}

Social inequalities in health are not new phenomena. E. Favereau ${ }^{2}$ notes in a column "aux petits cares" of the newspaper Liberation of January 28, 2020: "Professor A. Spira gave a few facts linked to social inequalities by recalling that in $1823 \mathrm{~L}$. Villerme published an article on particular mortality in poor districts of Paris, specifying that wealth, ease and misery are the main causes of the large differences in mortality". B-P. Lécuyer and E. Brian ${ }^{3}$ confirm this assertion. On the other hand, the DREES 4 file notes that: "the scientific literature has already highlighted the presence of social inequalities in past epidemics. This phenomenon results from three factors, often cumulative: i) inequalities in the risk of exposure, ii) differentiated vulnerability to the disease and iii) differences in care". The report adds that: "to health inequalities in the face of the pandemic have been added a second phenomenon, just as striking: social inequalities in the face of confinement". The study certainly concerns the French context; these inequalities are even more accentuated when we look at what is happening in poor countries faced with poverty, conflict, bad governance, corruption and the very apprehension of the concept of pandemic which people consider it as an action program of the rulers. The Covid 19 pandemic has accentuated these inequalities and one can wonder how the reactions of the advanced countries will be in the face of the situations of the poor countries; we will remember the attempts by some to seize the means to fight and prevent the pandemic as soon as it appears. This pandemic is not, however, the first to have known the world; there are so many examples ; we can cite: i) the Spanish flu, with a particularly deadly virus, which was grafted on the First World War, ii) the great economic depression of 1929 in the USA which spread to the world over the 1930s, iii) the Antonina plague which struck the Roman Empire at the end of the Antonina dynasty, iv) the plague of Athens which ravaged Greece from 430 to $426 \mathrm{BC}$. $A D, v)$ the bubonic plague which reappeared in 1320 in Mongolia and appeared in the West in 1347 brought by Genoese sailors and killing 25 to 40million Europeans, cholera, vi) typhus, vii ) tuberculosis, viii) $\mathrm{VIH}$, and so one.

In developing countries, poverty has a whole different meaning than in technologically advanced countries where "poverty lines" are established; this threshold is set at around $1000 €$ of net monthly income for the French context for example; it can be the equivalent of a daily bowl of rice to survive in some poor countries; the Inequalities Observatory notes in its edition of September 18, 2020: "1\% of the world population owns $44 \%$ of all the world's private wealth". Education is another factor of social inequality that increases health inequality. Ethnic origin is also another factor of social inequality and therefore of health inequality; the most striking example is given by the USA. 
Poverty is not the only factor aggravating social and therefore health inequalities; the chronic mistrust of the citizen vis-à-vis the system of governance is another important element in the very understanding of the concept of a pandemic. Many citizens believe, deep down, that the pandemic is a creation of political powers to strengthen their hold on society, put an end to popular demands and weaken opposing movements; the stopping of the peaceful citizen movement in Algeria "the Hirak", the arrest of many activists presumed to be leaders of the protest movement, the organization of the referendum for the constitutional revision in the midst of a health crisis, the idea of organizing local elections and legislative in full period of confinement are so many examples to illustrate our remarks ; in France, the suspension of the "yellow vests" (les gilets jaunes) movement is another example.

The health crisis that the world is going through has highlighted the inequalities of which we speak so little so much that they have been trivialized: i) the fragility of the populations in the disadvantaged cities of certain technologically advanced countries; we realize the urgent need to take charge of these populations as a measure of protection of society as a whole; ii) the fragility of black populations in the USA which leads to unpredictable reactions; iii) the fragility of the populations of developing countries who can spread the virus through interposed travelers: tourists, binational going to or returning from their families, other officials or private workers posted in developing countries and repatriated to their homes. In general, disadvantaged populations who suffer in silence and discretion become more visible because of the unavoidable interdependence and the transmission of a virus that is still poorly understood. The strategies for combating the pandemic in technologically advanced countries must therefore include disadvantaged populations.

In addition, in many developing countries, corruption, almost trivialized, increases mistrust in the systems and powers of governance. The citizen accepts the fact of a pandemic only when the fatal outcome reaches his relatives. Some of our contacts in Algeria whom we had questioned on the establishment of barrier gestures (in particular distancing) in places of worship (mosque) answered us: "in the tradition of the prophet, we pray while being glued together. To others to express solidarity; we cannot imagine prayer keeping distances between the faithful; we prefer to say our prayers at home"; they implicitly consider that prayer in the conditions of distancing is null. From our reading of the Coran, we did not detect any verse, which stipulates this rule; perhaps we have not been sufficiently precise or careful in our reading of the Text; but we don't think prayer would be null if we keep away from each other. To confirm our affirmation, we need only remember the prayers of the days of Eid (end of Ramadan), which bring together many faithful, some of whom are so distant from the Imam and other faithful; are their prayers null for all that? We think no.

The delimitation of state borders after decolonization or even before when the territories were divided between conquering countries has left its mark by creating social inequalities and even conflicts. There are many examples: i) the latent white-black conflict in the United States which still results in inequalities in health conditions, ii) the increase in the fragility of classes of citizens in France (those with an emigrant background, the "at risk" cities, the students until then considered as privileged populations), iii) the barely veiled ArabBerber face-to-face meetings in the Maghreb countries, iv) the IsraeliArab conflict which erased the historical understanding of the Jewish and Arab populations by replacing it with inextricable political and geographical situations, v) the classes of populations in India, vi) the opposition of the rich and the poor in the world! So many examples, so many arguments that lead us to recall the question that many analysts are already asking themselves, consisting in reconsidering the distribution of labor, profits and wealth in the world.

We will add to this the mainly moral issue of the responsibility of technologically advanced countries and their debt vis-à-vis the poor countries, generally former colonies providing wealth and cheap labor.

The present work does not claim to answer all such complex questions; he proposes at least to ask them or recall them. We will examine inequalities in public health. We will also deal, by way of illustration, with the case of a particular Maghreb country, which can be considered, from several angles, as representative of this region despite the differences in political regimes.

\section{Social inequalities}

As mentioned above, the world experiences multiple social inequalities: hunger, poverty, work, health, well-being, constraints of daily life, social pressures, systems of governance and their implications on populations, hopes finally for the future for some, for the bitter reality of the present for many others, the forgotten in this world and the marginalized present in technologically advanced countries.

\section{Wealth of some, poverty of others}

The Inequalities Observatory ${ }^{9}$ states that 47 million people with an estimated wealth of more than U\$ 1million hold $43.9 \%$ of the world's wealth. Table 1 shows us the GDP per capita in 2019 of some significant examples of poor countries and rich countries taken from the planner "ACONTRESENS", citing the World Bank database; note the significant difference in GDP per capita in 2019: this factor varies from 283 for South Sudan to 166,726 for Monaco, i.e. a ratio of 589 between the country with the highest GDP per capita and the country with the lowest GDP per capita ; the ratio of averages between rich countries and poor countries is equal to 155: igures that make you dizzy and push us to question the causes of these inequalities, the responsibilities of the most advanced but also the most disadvantaged, to wonder about the possible means of reducing these inequalities or at least making them more bearable.

\section{Poverty also translates into access to improved water resources}

People in rich countries have access to improved drinking water sources: an advantage, or rather a luxury, that those in poor countries cannot even dream of: global health statistics for 2009 indicate that this access is $100 / 100$ for North America and Europe ; it would be between 19 for Guinea and 45 for Mali; the fact that this factor is not zero does not mean that the Lambda citizen has access to these sources because there is the biasing effect of the presence of tourists and operators from rich countries which requires having a minimum of attractive factors. It is 92 for Algeria, where sufficiently well-off citizens do not trust the production and control systems of running drinking water and can thus afford to obtain mineral water; the others, having no other choice, are content with tap water.

\section{Access to healthcare is another factor of inequality}

The number of doctors per 10,000 inhabitants: The 2015 WHO report provide the number of doctors per 10,000 inhabitants; we have taken examples from rich and poor countries to compare. The data are provided by Table 2; for poor countries, the number of doctors varies from 1 for East Africa to 10 for Pakistan; the average number of doctors per 10,000 inhabitants is 41 for rich countries and only 7 for poor countries; the ratio is thus 5.8 . 
Table I Example of inequalities according to GDP per capita in the world in 2019

\begin{tabular}{ll}
\hline Countries & PIB by inhabitant \\
\hline Soudan du Sud & 283 \\
Burundi & 275 \\
Malawi & 389 \\
Madagascar & 461 \\
Niger & 412 \\
Afganistan & 521 \\
Moyenne: & 390,2 \\
Monaco & 166726 \\
Luxembourg & 114340 \\
USA & 62641 \\
Danemark & 60596 \\
Suède & 54112 \\
Allemagne & 481,96 \\
Belgique & 46556 \\
Canada & 46125 \\
France & 41464 \\
Chine & 9771 \\
\hline moyenne : & $6028 I, 3$ \\
ratio riches/Poor : & 155 \\
\hline Rich countries
\end{tabular}

Realization:Abdellaoui A

Sources: le planificateur ACONTRESENS

https://planificateur.a-contresens.net/classement_par_pays/pib_par_habitant. html

Table 2 Number of doctors for 10000 inhabitants

\begin{tabular}{ll}
\hline Countries & Doctors numb/l 0000 inhab \\
\hline Norvège & 44 \\
Allemagne & 42 \\
Russie & 40 \\
Italie & 39 \\
Espagne & 39 \\
France & 32 \\
Average: & 41 \\
Afrique de l'Est & 1 \\
Thailande & 5 \\
Vietnam & 8 \\
Sri Lanka & 9 \\
Pakistan & 10 \\
Average : & 7 \\
\hline
\end{tabular}

Realisation:Abdellaoui A

Source:WHO report 2015
National health spending: World health statistics ${ }^{5}$ provide us with an estimate of national health expenditure by region and country; world health statistics (2009) provide us an estimate of national health expenditure by region and country; we have extracted certain data which appear to us to be significant in order to reflect the inequalities. Table 3 shows us the information concerning: i) on the one hand the America, Europe and East Mediterranean regions compared to the Africa and South East Asia regions considered to be the poorest and ii) on the other hand the countries Canada and Bahrain, which we consider to be sufficiently representative of countries with high health expenditure compared with Angola, Bangladesh, Benin and Cameroon with low health expenditure. We can thus notice that the expenses of the "rich" countries are almost five times (4.8) greater than that of the developing countries. The inequalities are significant.

Table 3 National private health expenditure (PVT-D) per capita in US\$

\begin{tabular}{|c|c|c|c|c|c|c|}
\hline Regions & 2003 & 2005 & 2009 & 2012 & 2015 & 2017 \\
\hline Amérique & 231,9 & 275,5 & 351,6 & 409,1 & 409,7 & 432,6 \\
\hline Europe & 405,2 & 506,4 & 645,5 & 690,9 & 667,0 & 706,9 \\
\hline $\begin{array}{l}\text { Est } \\
\text { Méditerranée }\end{array}$ & 98,2 & 107,1 & $\mid 43, I$ & 164,1 & 245,4 & 176,0 \\
\hline Afrique & 27,9 & 35,7 & 49,3 & 51,5 & 52,6 & 51,6 \\
\hline Asie Sud Est & 27,2 & 35,2 & 46,8 & 61,8 & 60,5 & 66,8 \\
\hline Average & I58,I & 192,0 & 247,3 & 275,5 & 287,0 & 286,8 \\
\hline Average & 27,6 & 35,5 & 48,1 & 56,7 & 56,6 & 59,2 \\
\hline $\begin{array}{l}\text { Ratio: PVD/ } \\
\text { PD }\end{array}$ & $17,4 \%$ & $18,5 \%$ & $19,4 \%$ & $20,6 \%$ & $19,7 \%$ & $20,6 \%$ \\
\hline \multicolumn{7}{|l|}{ Pays } \\
\hline Algérie & 17,5 & 30,7 & 60,3 & 90,3 & 85,7 & 87,9 \\
\hline Angola & 20 & 28,1 & 34,1 & 39,8 & 54,3 & 57,9 \\
\hline Bangladesh & 6,5 & 7,7 & 12,2 & 16 & 23,7 & 27,8 \\
\hline Benin & 12,5 & 13,6 & 15,8 & 16,4 & 14,3 & 15,6 \\
\hline Cameroun & 30,3 & 34,6 & 46,1 & 49,1 & 49,4 & 53,5 \\
\hline moyenne & 17,36 & 22,94 & 33,7 & 42,32 & 45,48 & 48,54 \\
\hline Canada & 685,3 & 885,2 & II 26,8 & 1378,4 & 1152,6 & 1249,7 \\
\hline Bahrein & 213,1 & 184,7 & 283,5 & 336,5 & 396,4 & 473,7 \\
\hline Average & 449,2 & 534,95 & 705,15 & 857,45 & 774,5 & 861,7 \\
\hline $\begin{array}{l}\text { ratio PVD/ } \\
\text { PD }\end{array}$ & $3,86 \%$ & $4,29 \%$ & $4,78 \%$ & $4,94 \%$ & $5,87 \%$ & $5,63 \%$ \\
\hline
\end{tabular}

Realisation:Abdellaoui $\mathrm{A}$

Source:WHO 2020

Chronic diseases: Developing countries and technologically advanced countries face the disease differently. While malaria is eradicated in North America and Europe, African countries are still at risk. The WHO Global Malaria Report ${ }^{10}$ mentioned: " Globally, the number of malaria cases is estimated at 228million in 2018, compared to 251 million in 2010 and 231 million in $2017 »$. This report indicates that: « Most cases (213million or 93\%) were recorded in 2018 in the WHO Africa region, far ahead of the South-East Asia region (3.4\%) and the Eastern Mediterranean region (2.1\%) ». ${ }^{11}$ 
We can note then that nineteen countries in sub-Saharan Africa and India have concentrated almost $85 \%$ of the total number of malaria cases worldwide. Six countries alone have recorded more than half of the cases: Nigeria (25\%), the Democratic Republic of Congo (12\%), Uganda (5\%), as well as Côte d'Ivoire, Mozambique and Niger (4\% each). Still for malaria, the number of cases notified was in 2010, for example: 2,417,780 for the Democratic Republic of Congo, 1,620,840 for Sudan, 617,101 for Togo. Malnutrition is another scourge that developing countries often have to fight with limited resources. The Table 4, extracted from WHO's statistical word in 2012 indicates us Africa's death countries by various diseases: malaria, VIH and tuberculosis taken as an example here.

Table 4 Africa's death rate by countries

\begin{tabular}{llll}
\hline $\begin{array}{l}\text { Africa: death } \\
\text { rate for } \\
\text { 100000 inhab }\end{array}$ & $\begin{array}{l}\text { Malariar } \\
\text { (2008) }\end{array}$ & VIH (2009) & $\begin{array}{l}\text { Tuberculosis } \\
\text { (not VIH) 2010 }\end{array}$ \\
\hline Gabon & 31 & 164 & 70 \\
Gambia & 43 & 93 & 49 \\
Ghana & 48 & 74 & 87 \\
Guinée & 165 & 46 & 59 \\
Guinée Bissau & 203 & 73 & 27 \\
Kenya & 12 & 201 & 17 \\
\hline
\end{tabular}

Realization:Abdellaoui A

Socio-health protection: Advanced countries have adopted different strategies for the social and health protection of citizens: in the United States, only the richest can have social and health coverage protecting them from disease; in Europe, where the informal sector is rare, employees have numerous social security schemes and complementary mutual; In developing countries, informal work and trade are common and affected citizens cannot have health coverage. According to Fall A. " "In Africa, only $5 \%$ to $10 \%$ of the working population benefits from social coverage". The International Labor Organization (ILO) notes that the situation has deteriorated over the past twentyyears. She points out that: "nearly $80 \%$ of the population does not have access to basic health care". WHO report (2012) indicates the risk factor's regions to WHO (low birth weight) as shown in Table 5.

Table 5 Risk factor by WHO's region

\begin{tabular}{ll}
\hline Regions : Risk factors & Low birth weith (\%) 2005-2010 \\
\hline Africa & 13 \\
Americas & 8 \\
South East Asia & 24 \\
Europe & 7 \\
eastern mediterranean & 21 \\
Western Pacific & 5 \\
\hline
\end{tabular}

Realization:Abdellaoui A

\section{Mortality rates, a factor aggravating inequalities}

Major causes of death: Picheral $\mathrm{H}^{7}$ indicates that the share of the causes of death in 1985 were: i) for infectious diseases: $4.6 \%$ for developed countries and $45 \%$ for developing countries, ii) for acute respiratory diseases: $3 \%$ for developed countries and $16.6 \%$ for developing countries, iii) for cancers: $20.8 \%$ for developed countries and $6.6 \%$ for developing countries. The developing countries are still influenced by the causes of well-treated diseases in developed countries; one can then ask the question of why the know-how of developed countries is not transmitted to developing countries; but the reason can also be the lack of means available in the developing countries, or the system of governance which does not follow; many other reasons can be mentioned. We extract from WHO's report (2012) the statistical death rate per 100000 hab for three examples for diseases: malaria, VIH and tuberculosis; this shown in Table 6.

Table 6 Africa's death rate by WHO's region

\begin{tabular}{llll}
\hline Region & $\begin{array}{l}\text { 5-Year-old } \\
\text { mortality rater } \\
\text { death per } 1000 \\
\text { birth 2009 }\end{array}$ & $\begin{array}{l}\text { Life } \\
\text { espectancy } \\
\text { at } 60 \text { year } \\
\text { men 2009 }\end{array}$ & $\begin{array}{l}\text { Life } \\
\text { espectancy } \\
\text { at 60 year } \\
\text { women 2009 }\end{array}$ \\
\hline Africa & 54 & 14 & 16 \\
Americas & 76 & 21 & 24 \\
South East Asia & 59 & 16 & 18 \\
Europe & 75 & 19 & 23 \\
$\begin{array}{l}\text { eastern } \\
\text { mediterranean }\end{array}$ & 66 & 16 & 18 \\
Western Pacific & 75 & 19 & 22 \\
\hline
\end{tabular}

Realization:Abdellaoui A

Malaria mortality rate: Global health statistics for 2009 tell us that this rate is $0 \%$ for North America and Europe; it is $80 \%$ for Senegal, $164 \%$ for Guinea, $171 \%$ for Liberia, and $201 \%$ for Mali. While malaria is eradicated in developed countries, one wonders why it should not be in developing countries. Could it be a problem of local resources, know-how, health policy, customs or health education? Do developed countries have some responsibility for the current situation of developing countries?

\section{Life expectancy}

Duthé $\mathrm{G}$ et al. ${ }^{8}$ give an estimate of life expectancies at birth and at age 60 in 2000-2005; if we consider life expectancies at birth, they would be: i) globally for the world respectively 63.9 years for men and 68.3years for women; ii) for Europe respectively 69.6years for men and 78years for women; iii) for sub-Saharan Africa, the Figures drop to 47.6 for men and 49.9 for women. While the Figures for Europe are closer to those for the world, those for sub-Saharan Africa are far removed, and there is a ratio of 1.5 between the Figures for Europe and those for sub-Saharan Africa. Pison $\mathrm{G}^{1}$ gives the risks for a newborn baby to die before reaching 5years: this risk is estimated at less than $10 \%$ for North America and Europe, for South America it is between 10 and 99, for the Maghreb between 10 and 49, for sub-Saharan Africa it is estimated at more than 150 . These two studies show the great inequalities between developed countries and poor countries. Table 7 shown the children's mortality life and life expectancy in a few countries in Africa; the data are extracted from WHO statistical report (2012).

\section{The health crisis: an aggravating factor of inequalities}

We note, even in technologically and socially developed countries, the increase in the number of citizens plunged into need, even below the poverty line; in developing countries the situation is even more complex, more painful, and more inextricable. The World Bank (2020) notes that: "It \{a health crisis\} painfully sheds light on the persistent situation of disadvantaged and vulnerable groups whose permanent suffering is now exacerbated: the elderly, First Nations communities, Inuit and Métis, radicalized and ethnic groups, incarcerated people, 
migrant workers, asylum seekers, refugees, people with disabilities, the poor, the homeless, women and children victims of domestic violence. The report notes that if these people cannot be treated and taken care of, the risk of infection is widespread throughout society. The care of these vulnerable people no longer appears as a moral duty to help the poor but as self-protection, in other words an act dictated by the imperative of survival. When researching anti-covid vaccines, the issues on the agenda in advanced countries are: what funding should we mobilize, how much should we budget for our contexts; no nation asks itself the question of reserving vaccines for those who cannot afford it: poor countries, areas in conflict, societies subject to illegitimate or puppet governance. All these "others", these are forever forgotten.

Table 7 Africa's mortality rate and life expectancy by countries

\begin{tabular}{llll}
\hline Africa & $\begin{array}{l}\text { 5-Year-old } \\
\text { mortality rater } \\
\text { death per 1000 } \\
\text { birth 2009 }\end{array}$ & $\begin{array}{l}\text { Life espectancy at } \\
\text { 60 year men 2009 }\end{array}$ & $\begin{array}{l}\text { Life } \\
\text { espectancy } \\
\text { at 60 year } \\
\text { women 2009 }\end{array}$ \\
\hline Gabon & 74 & 321 & 262 \\
Guinée & 130 & 474 & 369 \\
Mali & 15 & 357 & 218 \\
Mauritanie & 111 & 315 & 262 \\
Niger & 143 & 229 & 224 \\
Nigeria & 143 & 377 & 365 \\
\hline
\end{tabular}

Realization:Abdellaoui A

\section{A specific illustrative example:Algerian society}

The Maghreb, a strategic position: The Maghreb as a regional entity began to build from the end of the 1970s; it was to bring together Libya, Tunisia, Algeria, Morocco and Mauritania and thus constitute a powerful socio-political and geo-economic unit. Some wanted to go fast: we remember the action of Colonel Gaddafi rushing towards a border post between Libya and Tunisia with a tractor to signify the end of the borders. At the political level, a six-month rotating presidency was adopted and a project for a common Maghrebian identity card was under consideration. Both external and internal constraints ended up causing the failure of the "Maghreb" project which should have had every chance of succeeding by noting the common ancestral customs, the common religion, and the common fights. It is necessary to recall here some elements likely to enlighten us on the reasons of this failure: i) the drawing of the borders by the colonial powers left after-effects leading to bloody clashes (the border war between Algeria and Morocco which claimed certain regions such as that of Béchar; Algéria), to insoluble conflicts such as the question of Western Sahara claimed by Morocco; ii) the difference in the governance system between the different countries constituting the Maghreb has not meant to generate dissension and conflicts between partners; iii) the construction of a strong Maghreb would have put in place a bulwark between Europe and Africa and the fear of a barrier of influence, even of a trade barrier; iv) however, this project could have constituted a barrier to migratory flows and thus protected Europe ; in the case of the Covid-19 pandemic, a Maghrébine strategy could very probably have effectively protected both the Maghreb populations but also Europe.

Common points: The Maghreb (sometimes called the Arab Maghreb) is located at the crossroads of the Arab world and Mediterranean and African civilizations; For more than a millennium, it has formed a geographical unit culturally characterized by the fusion of Arab-
Berber elements If recent histories and political regimes differ, the Maghreb countries, in particular the three countries of the central Maghreb (Morocco, Algeria and Tunisia) have many points that can lead to assimilate them as the same socio-geographic space:

The relief: It is characterized by the great Atlas which is declined in Morocco by the Middle Atlas, the Anti Atlas and the High Atlas; it continues in Algeria through the two chains of the Tell Atlas and the Saharan Atlas; it finally ends in Tunisia with the Tunisian ridge. The relief is still characterized by the highlands in Morocco and Algeria and the vast plains in particular the Moroccan Rif and the Algerian Tell.

\section{Populations and spirituality}

The official religion in the Maghreb countries is Islam, practiced more or less rigorously here and there. In the three countries of the central Maghreb, we can recall the many mixing of populations through marriages. But societies have changed under the influence of both internal and external pressures. Societies are tossed between a rigorous practice of religion and the temptation to conquer new freedoms practiced by a technologically advanced Western world, both so near and so far. The question of the societal drift and the slide of Muslim societies in general, and Maghébin societies in particular, towards the increasingly marked delay in relation to high-tech and knowledge societies is not entirely new since reformist Muslim thinkers of the mid-19th century (such as the Persian Jamal al-Din al-Afghani, the Egyptian sheikh Muhammad Abdou or the Syrian Mohammed Rashid Rida) wondered about the backwardness in scientific and technical matters. These founding fathers of modern reformism were not addressing their criticisms of the way Islam was historically constructed but of the bad practice of Islam by Muslims. Thus, according to Hourani (1983), "al-Afghani (1838-1897), a great thinker of Islam as a religion and as a body of doctrines, reflected in depth on the causes of what he considered to be a decline of Muslim countries ".But, nearly half a century later, we are asking again the same question of the assimilation of the faith and its integration into the acts of the daily life of the Muslim; we cite for this purpose M. Shahrour (2019) who explores these questions and asks these same questions again. M. Arkoun (2016) mobilizes all the resources of linguistics, semiotics, the history of mentalities and sociology to deconstruct the classical discourse on the Koran. The reflection that we make of it in relation to the Algerian Society can, in some aspects, easily extend to the Muslim Society (or the community) in all latitudes.

\section{The Maghreb facing the covid 19 pandemic}

The Covid-19 pandemic has affected all societies and countries, which have reacted very differently. The pandemic has brought to light both the solidarity capacities of the populations and the selfcentered strategies of the governance systems, in particular to obtain the prevention and control tools as well as the vaccines recently announced. The three countries of the central Maghreb (Morocco, Algeria and Tunisia) have not escaped this rule. They have been unable to unite, failing to develop complementary strategies, in the face of the pandemic. What has been common, however, is the apprehension of the pandemic on the part of the citizen who deeply thinks that it is only an action by those in power to silence the claims. What is also common is a spirit of fatalism in a large part of the population: it had to happen and it did. A mixed fatalism (or outcome) of the understanding of spirituality; an understanding under the discreet but strong influence of certain currents such as Wahhabism which have been spreading their hegemony since the 1970s. A notable professor from the association of Muslim ulemas in Laghouat (Algeria) was 
one day accompanied by one of his students who wanted to show him a bookstore in the city; the student pointed out to his teacher the sheer number of books on the shelves. Never seen before, he told her. The teacher pulled out a few books and exclaimed: "rabbi yustour"; translate: "God protect us". The student was shocked because he did not understand the reaction to the wealth of the bookstore. The professor quickly understood the origin and the underhand influence of the hidden message that these books spread. This was happening in Algeria ; we are convinced that the same phenomenon was taking place in the other Maghreb countries.

\section{Socio-geographic presentation}

Algeria as a whole is deeply marked by its deep attachment to three essential elements which make, to some extent, its specificity: religion, family and friendship; She also has a link, which one could describe almost as emotional, to her army, which is both the symbol of independence and the guardian of national security and stability. The technical reports (WV4 and WV6) from WVS ${ }^{12-14}$ that we have consulted support us in these statements. These reports present the results of an international research project investigating the evolution of values and beliefs around the world and carried out through the collaboration of a large international network of contributors and researchers in the social sciences. Since 1981, samples from nearly 100 countries have been surveyed using a single questionnaire in each of six waves, the first of which dates back to 1981. The results of the two reports are given in the form of tables of occurrence over two periods: 1999-2004 (for the WV4 report) and 2010-2014 (for the WV6 report).It should be noted, however, that these results relate to small samples of respondents (around a thousand); they nevertheless give an indication of trends. From these data we have taken here the ten indicators, which seem to us the most apt to help us understand society. These indicators give on the one hand the importance of the topic in life and on the other hand the trust placed by society in institutions. The results are shown in Table 8 below. We can note that: i) the company gives almost $100 \%$ importance to religion, family, friendship and work practically over the two study periods; ii) but relatively little trust in public institutions (government, parliament and trade unions, in particular); this confidence deteriorates in the second study period. Confidence in the army remains relatively high, even for the second period (58\%) because it represents, in the eyes of society, a factor of stability and national cohesion, even if it played a key role in the designation of Rulers since independence; role she never gave up.

Table 8 Confidence to national institutions

Confidance rate in $\%$

\begin{tabular}{|c|c|c|c|c|c|}
\hline \multirow{2}{*}{ Indicator } & \multirow{2}{*}{ Code question } & \multicolumn{2}{|l|}{$1999-2004$} & \multicolumn{2}{|l|}{$2010-2014$} \\
\hline & & Important & Not important & Important & Not important \\
\hline importance of religion & A006 & 99 & 1 & 98 & 2 \\
\hline importance of family & A00I & 100 & 0 & 98 & 2 \\
\hline importance of God in life & F063 & 99 & 1 & 98 & 2 \\
\hline importance of frindship & A002 & 81 & 19 & 81 & 19 \\
\hline importance of leisure & A003 & 77 & 23 & 68 & 32 \\
\hline importance of work & A005 & 99 & 1 & 89 & 11 \\
\hline trust in government & E069.II & 54 & 46 & 40 & 60 \\
\hline confidence in parliament & E069.07 & 34 & 66 & 28 & 72 \\
\hline confidence in the armed forces & E069.02 & 68 & 32 & 58 & 42 \\
\hline confidence in national TV & E069.10 & 46 & 54 & 43 & 57 \\
\hline confidence in trade unions & E069.05 & 29 & 71 & 31 & 69 \\
\hline
\end{tabular}

Realization:Abdellaoui A

\section{Considering the support of the health system}

Algeria is at the bottom of the list. Indeed, according to the "Global Health Security index" published in 2019 (page 28), which reports countries according to their capacity to cope with international health crises, Algeria is considered to be one of the countries the "least prepared" and comes in 173rd place in the general classification which includes 194 countries (Figure 2, photo a). Photo (b) of Figure 2 represents the national commitment to improve national capacity in funding and compliance. Note that Algeria is at the level of Congo Brazzaville in (a) and at the level of Mauritius in (b).

\section{Societal level}

Algerian society has changed in recent decades; it is no longer what it was at the time of its struggle for independence or during the years following it in the process of rebuilding an independent state and a society animated by the hope of raising itself to the level free societies: free to choose, free to live, and free to hope. The systems of governance of the last decades have helped to erase these hopes by introducing the powerful links to profit, selfishness, mistrust, and ultimately trivialized corruption. In this societal change of the last twenty years, the individual looks differently at his neighbor or simply at the "Other" who is no longer a "fellow citizen" but a competitor who must be overtaken at every turn. He now sees his system of governance differently, his rulers in whom he no longer trusts. More generally in popular consciousness it is believed that the Administration is in its majority run by corrupt, opportunists, incompetent people, people placed by their peers to serve and nurture "a system" which is itself totally corrupt, for which even paying tax becomes sin. We forget that the system is also us together, it is each individual. The individual henceforth integrates the very concept of Nation and Fatherland in a different way to the point of no longer having the courage to project 
themselves inside, to the point of losing hope and forgetting that the Nation still has it. Ability to produce children who are able to stand up with a single strong voice to cry out their exasperation, despair and fed-up. The popular movement "Hirak" (Figure 3) has however shown that the young (and the not so young) are capable of maturity, peace, mutual aid, selflessness and hope.

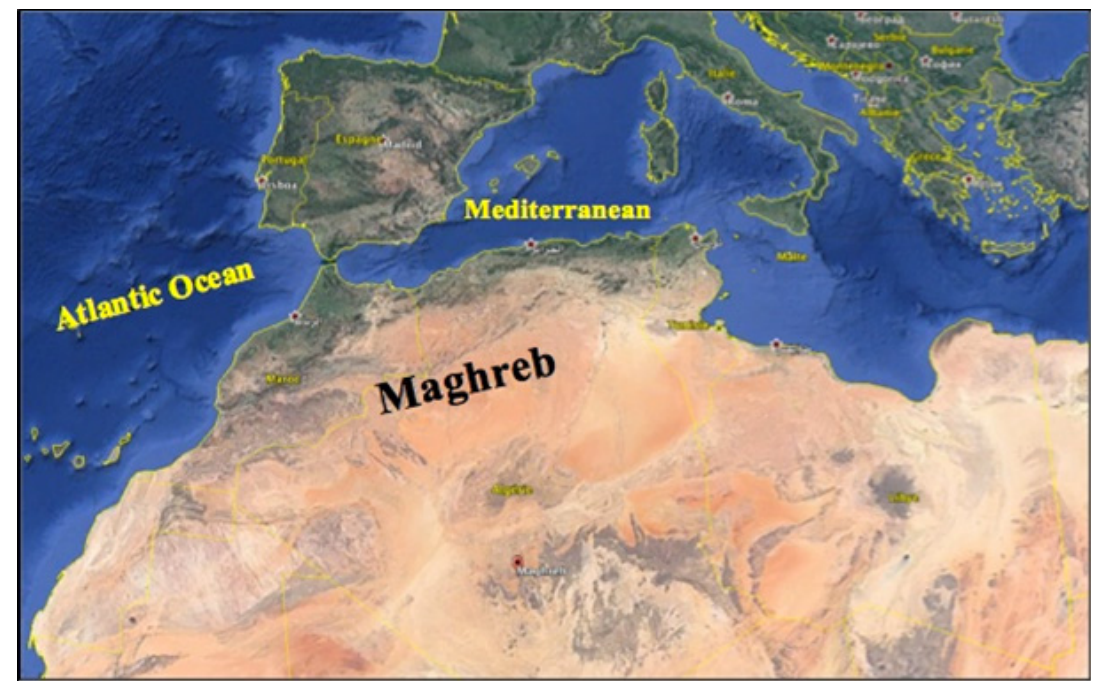

Figure I The Maghreb, a strategic position.

Realization:Abdellaoui A

\begin{tabular}{|c|c|c|c|}
\hline 170 & Angola & & 252 \\
\hline $17 \mid$ & Tonga & & 251 \\
\hline 172 & Dominica & & 240 \\
\hline 173 & Algeria & $A$ & 236 \\
\hline 174 & Congo Brazzaville & & 236 \\
\hline 175 & Djibouti & & 232 \\
\hline 183 & Irak & & 295 \\
\hline 184 & Algeria & B & 291 \\
\hline 185 & Mauritius & & 291 \\
\hline
\end{tabular}

Figure 2 Algeria in queue ( $a$ and $b$ ).

Realization:Abdellaoui A.

Sources: Global Health Security Index; 2019; (page 28).

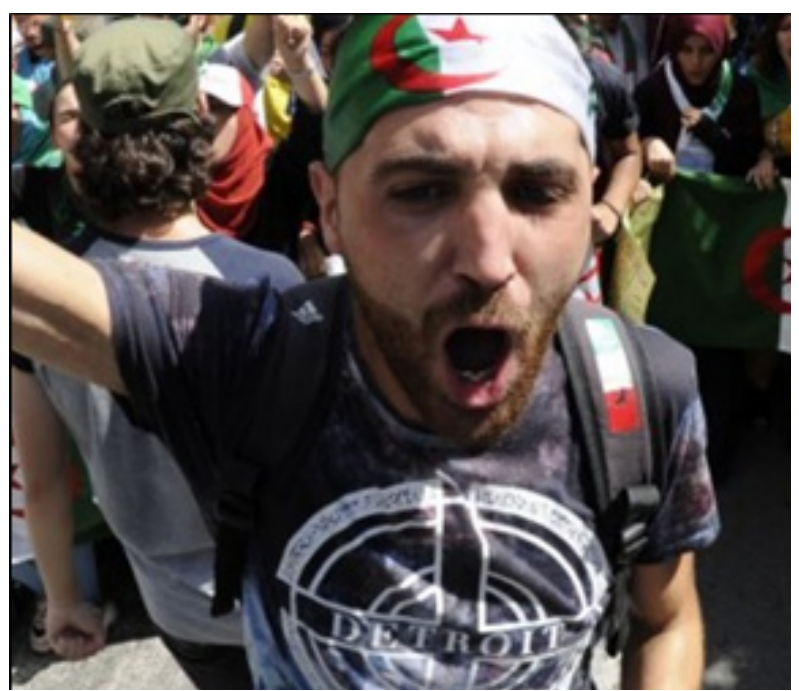

Figure 3 Anger - 2019, September 10.

\section{The Covid-I 9 pandemic in Algeria}

The pandemic was unexpected and President Tebboune declared last June: "our health system is the best in Africa". Affected by the virus, he had nevertheless been evacuated to Germany; his predecessor, President Bouteflika had received treatment in France. The pandemic has succeeded where power has failed: putting the Hirak (the peaceful citizen movement) on hold. However, initially, many Algerians did not believe it. Gatherings and demonstrations of all kinds (festivals, cultural or sporting events and even the Hirak) took place without concern. Many thought, and said loudly that it was just intoxication, a maneuver of the powers to silence citizen demands, even a global maneuver to reduce the world population, starting with the poorest. Later, still unaware of the gravity of the pandemic, some began to suggest solutions to be spared: from the "more natural" in a "believing" society to the most extravagant. The number of reported cases currently stands at more than 800 nationwide; but the Lambda citizen still does not believe in the pandemic whose first effects are to benefit parallel and informal trade. Even during the confinement decreed, some businesses invited their customers to buy and closed their doors to pretend to respect the confinement. A ubiquitous and anachronistic situation. When the instructions and protective measures against the virus were disseminated, in particular those concerning respect for distancing in places of worship, some faithful argued that the tradition of the prophet (messenger of God) consisted of praying in close ranks to express the solidarity of believers; distancing would have the effect, according to them, of nullifying prayer; another rigorist interpretation of the tradition.

\section{Social inequalities in Algeria}

\section{Employment and entrepreurship}

Very few graduates, and more specifically from higher education, find a job after their training; Two main reasons can be mentioned here: i) recruiting companies think that the university does not train enough for their objectives and constraints, ii) graduates have little training in entrepreneurship and graduates tend to wait offers them a job. At the same time, we meet many business leaders who have 
been trained on the job and have not acquired traditional training. Khaoua N. (2019) notes in this regard: "In fact, entrepreneurship, as presented, is only a survival action for social categories marginalized and neglected by public policies. A second striking example is that of university graduates: more than 300,000 university graduates, of whom at least 180,000 are women, cannot find jobs related to their training and diplomas. In fact, entrepreneurship, as presented, is only a survival action for social categories marginalized and neglected by public policies. A second striking example is that of university graduates: more than 300,000 graduates from universities, of which at least 180,000 are women, cannot find jobs commensurate with their training and qualifications.

\section{Legal pluralism and exclusion of women}

Women are under constant pressure on the streets, at work, at home sometimes: Ghraba Gh. (2013) notes that: This should not obscure the fact that political discourses of exclusion of women are still very largely based in our society on a biological, religious and patriarchal discourse. This paradoxical situation has made the woman a citizen in the public sphere since she can access all the elective as well as administrative functions, she is the master of her heritage and its management, but this does not prevent it. not to find herself in a situation of serious inferiority in family law, which means that a woman can be President of the Republic but that she must be legally assisted by her father to get married.

\section{The privileged}

Certain classes of society benefit from known or supposed particular advantages: access to employment, salary, access to housing, private infrastructure, pensions and so on. To this end, Khaoua (2015) asserts that $10 \%$ of socially privileged Algerians spend more than a quarter of total household expenditure, at a time when $80 \%$ of the population absorbs $60 \%$. Regarding the nature of the products consumed and purchased, official data show that $41 \%$ of the population's expenditure comes from $10 \%$ of the population and $28 \%$ from the most disadvantaged groups. To this end, Khaoua (2015) asserts that $10 \%$ of socially privileged Algerians spend more than a quarter of total household expenditure, at a time when $80 \%$ of the population absorbs $60 \%$. Regarding the nature of the products consumed and purchased, official data show that $41 \%$ of the population's expenditure comes from $10 \%$ of the population and $28 \%$ from the most disadvantaged groups. Sari (2006) notes, in relation to social inequalities in Algeria, that the compression of health spending and the dysfunction of public health structures reinforce a two-tier medicine with an aggravation of regional disparities. If the center region performs half of the surgical procedures against $7.7 \%$ for the whole of the great South and the ratio of doctors is $1 / 889$ inhabitants, the oscillations vary from $1 / 294$ (wilaya of Algiers) to 1/2664 (wilaya of Djelfa).

\section{Discussion}

We have mentioned the different socio-health inequalities between populations. We will try to discuss the probable causes in our text; we will endeavor above all to ask the questions inherent to these causes; the answers that we will try to propose obviously come from a long history of reflection on the subjects. Some people have already been asked by others. We will also suggest revisiting the Figures we had presented using graphs that seem more meaningful to us.

\section{Territorail divisions and drawing geographic borders}

The colonial powers had divided the territories according to their interests, but also, and above all, their weight at the time of the partitions. The examples are so numerous and one can go back to distant dates in the history of mankind from the first conquerors from distant Africa who delimited their territories in the most recent times: the Indian reserves where the indigenous people to delimit the spaces of the new occupants, the dormitory cities for the poor and marginalized in certain Western countries, the zones of influence after the two world wars and so many other examples. We will consider here four examples that do not seem worthy of interest:

\section{The algerian-maroco geographic borders}

They were almost drawn to the rule by the French colonial power and do not take into account local social realities. They generated armed conflicts between Algeria and Morocco as soon as Algeria gained independence; Morocco claimed a part of the territories, in particular in the region of Bechar (Algeria). This conflict has not failed to leave traces in Algerian-Moroccan relations.

\section{Rio Oro, former spanish colony}

Decolonization took place in total vagueness leaving a latent conflict and the possibility for the Moroccan regime to claim the territory called "Western Sahara" by elsewhere claimed by the local populations who express their right to self-determination to freely choose between independence and the creation of a sovereign state or to be attached to the Hashemite kingdom. But this conflict went beyond the confrontation between the Saharawi population and Morocco; some states support the Saharawi population in its demand for free choice; others Morocco for reasons of political interest, influence or business. But the situation has also generated a permanent conflict between two "brother" countries that many things could have led to building a strong regional space; which did not suit many Western and Eastern powers.

\section{The state of Israel and the Arab-Israeli conflict}

Arabs and Jews, and Muslims and Jews have always lived in harmony since ancient times; are they not all descendants of Abraham ? At the advent of Islam, the Jews lived in peace in Arabia and Medina; their presence was protected by the Messenger of God. Closer to us and in many countries such as the central Maghreb for example, the Jewish and Arab populations lived in harmony and accepted unions by marriage ; in Algeria, this situation would disappear when the colonial power decided to separate the two populations by granting a special status of "citizen" to the Jewish community. The creation of the state of Israel was decided by the Western colonial powers (under the influence of the Zionist movement). The choice of Palestine responded to the Zionist request referring to the Old Testament by arguing that Moses had brought his people back to Palestine. We can then ask the question how far we can go back in the history of mankind to draw territorial borders. In the time of Moses, why not. May why not before, at the time of the first African conquerors who would then claim Europe? But we could quite simply have stayed at the time when two communities, all together, cousins according to history, could have lived in hamonia but the interests (declared or hidden) of each other led to the most conflicts. Improbable for reason, for morality, for justice. The Western powers could have created two states (Arab and Jewish) whose borders they would draw validated by the Council of Nations. This would have avoided an inextricable conflict and the strong inequalities that we know between such a strong and universally supported state (Israel) and a population in total destitution in Ghaza. A conflict that opposes two ways of having freedom of choice.

\section{The machrek royalty}

We can remember that all the Middle East kingships were created by the British Empire to have small and easily controlled territories (Lawrence d'Arabie project); they tried to put at their head docile 
people, allied to their particular interests. Thereafter, the Arab royalty subsequently consolidated their systems of governance and their power by declaring themselves, often, as representatives of Islam. It must be remembered, however, that the Messenger of God, Muhammed, saw himself as a messenger of God, not a representative of Islam. He has not appointed a successor, recommending that Muslims community to resolve their common problems through consultation. We can ask here the question of knowing why not grant to the holy places of Islam a status analogous to what exists for the Christian religion: a kind of Vatican; the same situation could be imagined for the holy places of Judaism. This would end many conflicts.

\section{Other examples}

Other examples exist around the world; they could have been avoided if the world powers had been able to convince themselves to abandon part of their individual interests in favor of the global interest for the planet: Afghanistan, Armenia, Vietnam... the regions of Africa and many others. 'other. Wherever borders of interest of influence or trade had been drawn in spite of common sense, morality, a long-term vision on the future of our planet, our space of life (or survival) to all.

\section{Health inequalities}

They can be evidenced by many factors such as: i) the number of doctors per so many inhabitants; this factor reflects the theoretical ease of a citizen to consult and seek treatment if necessary; ii) national health expenditure which informs us about the capacity of the citizen to take charge of the governance system; iii) major causes of death; this factor indicates the risk of being affected by diseases that are present and not yet eradicated; iv) the risks of mortality at birth; this factor tells us about the theoretical life expectancy at birth; v) the share of large cases of deaths at a given time; this estimated factor informs us about the presence of public health risks. Figure 4 in the following paragraph details this different factor in comparative analyzes between rich and poor. So what are the solutions?
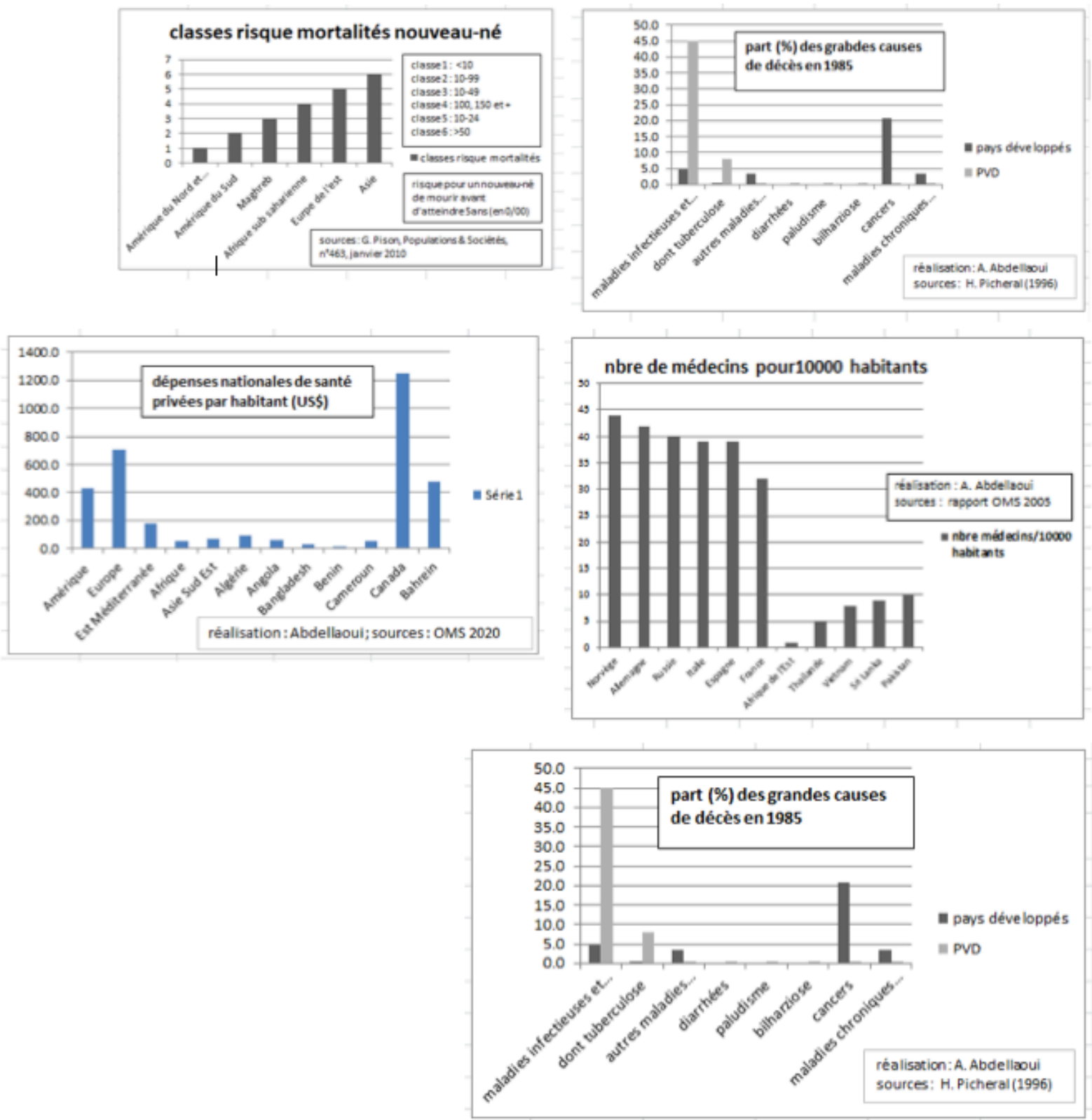

Figure 4 Inequalities according to several factors. 


\section{The lack of doctors in developping countries}

Examination of Figure 4 leaves us in tears when we see that East Africa has only one doctor per 10,000 inhabitants compared to what is available in Europe. It is of course possible to imagine training assistance programs: i) welcoming students from developing countries to universities in developed countries or ii) sending trainers to developing countries; this solution requires the mobilization of a large staff and, above all, international coordination which is difficult to implement; China, for example, offers numerous scholarships to strengthen its presence in Africa. The first solution will inevitably lead to the fact that those trained fall under the temptation to settle in the host country because of the enormous difference in living conditions with their country of origin: daily comfort and freedoms, in particular. The Malian students succeeded in finding a solution consisting in organizing themselves to collectively contribute to the improvement of living conditions in their country of origin while remaining in the host country. At the end of the $80 \mathrm{~s}$, beginning of the $90 \mathrm{~s}$, we helped to gain acceptance, within the framework of the remote sensing network of the University of French Expression Networks (UREF), of the idea of integrating an allowance into training campaigns. Return consisting of a salary supplement to students returning home after their training. We believe that this idea can be taken up and possibly readapted to large-scale training programs in doctors for developing countries; these programs were to be sponsored by WHO, or better still, UNESCO.

\section{Eradication of infectitus diseases}

We should first ask ourselves why these diseases are still present and cause so many regrettable deaths. Perhaps scientific studies have already done this; we can cite as an example; i) WHO world health statistics - 2015, ii) the article by A. Lopez ${ }^{15}$ on health in transition in Reunion from 1946 to 1986 , iii) the article by Picheral $\mathrm{H}^{7}$ health transition in the world; these works, far from being the only ones, are mentioned here only as examples among many others. The problem lies in reading and applying the results of this work, which unfortunately and very often ends up in the libraries, and drawers of the scientific community. So what solution? It is important that the international community finally decides to admit that the health of some can have unexpected repercussions for others; the covid-19 pandemic has amply demonstrated this; but the spirit of selfprotection and individual protection still prevails in the world. We believe it is possible to suggest that WHO open up frankly, honestly and completely to its role as a true international organization free from multiple pressures and harmful influences. WHO should therefore set up an independent international commission to reflect on the burning issue of disease eradication and improvement of health conditions for poor populations around the world; this program should inevitably incorporate a health education and awareness campaign.

\section{National health expenditure in developping countries}

Health spending strategies in developing countries do not obey Western logic; corruption, conflicts, interests and competing forces generate a logic where the interest of the citizen often comes last; it is difficult for the international community to interfere in internal policies under penalty of rekindling the colonial and imperialist character. For this question too, it is possible to imagine that WHO, with the support of the UN, could set up an independent think tank to propose scenarios of solutions to this very thorny question.

\section{Wealth and poverty}

We have seen (Table 1) that the GDP per capita is $\$ 275$ for Burundi while it amounts to 166,726 for Monaco: a staggering ratio of 606 between the rich and the poor! The Inequalities Observatory indicates that " $1 \%$ of the population has close to the world's wealth"; another mind-boggling Figure. Brzezinski (1981) states "We are all increasingly dependent on developing nations which provide outlets for Western capital and goods as well as sources of supply - both in finished articles and in raw materials." Buffet $\mathrm{MG}^{16}$ asserts: "There is no definition of the Western world. It is a long history that has allowed the construction of a representation with a hegemonic vocation. It is a culture, a form of collective consciousness. It is a myth associated with ideas of modernity, unity, humanity ... It is a geopolitical and even economic reality "Their role is no longer passive as in the past". The Western world (and the states that claim it), currently the richest, is built on the basis of a capitalist system, relies on private ownership of the means of production and encourages consumption to make profitable (and strengthen) these means. In these systems, rich and poor do not have the same consumption strategies: while some have full freedom of choice, others are subject to the inevitable pressures of their economic or social conditions. We can then ask the question whether it is possible to imagine tools for better distribution of wealth: giving a little to the poorest of what the richest earn. ${ }^{17}$ The term "give" is not the most suitable: when we receive without work, we do not give what is received its true value and we can then take pleasure in a waitand-see situation; one can remember for this purpose the example of the (interested) aid of the USA to an African country consisting in providing free milk powder for two or three years ; the farmers, believing that the aid would be lasting and seeing their customers turn to the free offer, sold their cows ; the aid then stopped and we started buying the powdered milk. Apply a wealth tax? Some states have tried the experiment and quickly reversed their decisions because of the leakage of fortunes. So what solution? One could imagine, as part of the environmental protection protocol, incorporating a carbon tax in states that would be levied on individuals according to their fortunes (variable rate over wealth ranges); the recoiled amounts would be partially donated to the poorest states (what criteria) to set up production systems and consumption policies that preserve the environment. ${ }^{18}$

\section{Conclusion}

In this article, we have recalled the inequalities, particularly in the areas of health (access to health care, mortality, chronic diseases, health expenditure) and the distribution of wealth by means of GDP per capita. We have attempted to examine the causes of these inequalities by proposing solutions that seem innovative to us. The adoption of these solutions will not be easy because of the multiple pressures due to the interests of each other. Two outstanding facts will be recalled here: i) the decision of the President of the United States to withdraw from the agreement on the environment and ii) the emergency resolution of the European Parliament in twenty points on Algeria; point (2) of this resolution "invites the Algerian authorities to release immediately, without conditions, ..."; one can wonder about the chance that this resolution is heard by the powers that be. This is not specific to Algeria and represents, for any sovereign state, an act of interference in the process of internal national politics.

We also presented the case of a Maghreb country whose inequalities are exacerbated by Covid-19 and where the pandemic was not taken seriously until it started to have significant impacts. We have tried to show, through this example, that there are global issues that need to be resolved on a planetary scale and not selfishly local. The future of Humanity is a global and serious problem requiring essential consultation, inevitable concessions, the recognition of all of the responsibilities of misfortunes and their effects and of the capacity of ALL to help build a better world. Certainly, some powers 
are racing in space exploration and the possibility of bringing back resources which are beginning to be lacking on earth; these powers also envisage the continuation of the human species in other spaces. It is certain that in such visions and strategies only certain privileged nations are concerned; nations lagging behind in science or technology are obviously excluded from the discussion because they cannot contribute anything for the moment. We can then ask ourselves what the future would be for poor populations in technologically advanced countries!

\section{Acknowledgments}

None.

\section{Conflicts of interest}

The authors declare that they have no competing interests.

\section{Funding}

There is no funding declaration to report from third party.

\section{References}

1. Pison G. The decline in child mortality in the world: great inequalities between countries. Populations \& Societies. 2010;463.

2. Favereau E. Health inequalities are in great shape. Release. Chronic $\mathrm{Ca}$ ring. 2020.

3. Lécuyer BP, Brian E. Money, Life, Death: Louis-Rné Villerme's Social Research on Differential Mortality by Income (1822-1830). Math \& Sci Hmm. 2000;149:31-60.

4. DREES. Social inequalities in the face of the Covid-19 epidemic. In: Dubost CL, Pollak C, Rey S, editors. Department of Research, Studies, Evaluation and Statistics (DREES). 2020.

5. Fall-Diop Assane. Between the deficiencies of states and dogmatism of donors. Battles for Social Protection in Africa. The Diplomatic World. 2006:22.
6. World Health Organization (WHO). World health statistics - 2009. Geneva, Switzerland: World Health Organization (WHO); 2009. 978924 2563818.

7. Picheral H. The health transition in the world. Bull Assoc Géogr Franç. $1996 ; 75-85$.

8. Duthé G, Laurent R, Pison G. Live and die after 60years in rural Africa. INED. 2009;160.

9. Observatory of inequalities. $1 \%$ of the population owns nearly half of the world's wealth. 2020.

10. World Health Organization (WHO). Global Health Observatory data repository. Geneva, Switzerland: World Health Organization (WHO); 2020.

11. https://apps.who.int/gho/data/node.main.GHEDPVTDpcUSSHA2011?lang=en

12. WVS. WVS. WV4_Results_By_Country; technical record; Study \#; v20180912; period: 1999-2004. 2018.

13. WVS.WV6_Results_By_Country; technical record; Study \#; v20180912; period: $2010-2014.2018$.

14. WVS.WV4_Results_By_Country; technical record; Study \#; v20180912; period: $1999-2004.2018$.

15. Lopez A. Health in transition at the meeting from 1949 to 1989: upheaval and the limits of the conquests of health in an overseas department. Annales de Géographie. 1989;98(546):152-178.

16. Buffet MG. From the Western World to the Age of Mankind: a Necessary Revolution. International and Strategic Review. 2009;(3):61-68

17. Le Monde diplomatique. 2006.

18. World Health Organization (WHO). Report on health in the world; 2003; Shaping the Future.

19. Geneva, Switzerland: World Health Organization (WHO); 2003. p. 193. 